American Journal of Applied Sciences 8 (5): 441-446, 2011

ISSN 1546-9239

(C) 2010 Science Publications

\title{
A Qualitative Approach of Identifying Major Cost Influencing Factors in Palm Oil Mills and the Relations towards Production Cost of Crude Palm Oil
}

\author{
Elaine Lau Ying Man and Adam Baharum \\ Department of Operation Research, \\ School of Mathematical Science, \\ University Sains Malaysia, 11800 Pulau Pinang
}

\begin{abstract}
Problem statement: The oil palm industry, which heavily depends on the world market, is an export oriented industry. World's palm oil consumption was growing over the years. In addition, Indonesia and Malaysia dominated the oil palm industry. The oil palm industry in Malaysia is very competitive and become one of the major economic sectors contributing to the total revenue of the country. In year 2009, there was a total of 22.40 million tons of oil palm products including palm oil, palm kernel oil, palm kernel cake, oleo-chemicals and finished products, equivalent to RM 49.59 billion of export revenue. However, cost of production for Crude Palm Oil (CPO) varies in a big gap. Therefore, it is essential to identify the major cost influencing factors in the production of CPO. Approach: The study system started with collection of Fresh Fruits Bunches (FFB) from oil palm plantation to the production of CPO at palm oil mills. Two palm oil mills of different production capacity were chosen for this study. Statistical analysis was done to identify the major cost influencing factors of production cost for CPO. Results: The production cost of CPO for small scale palm oil mills preferably lied between RM 45 to RM 50 per metric tons while large scale palm oil mills lied below RM 45 per metric tons. Conclusion: Palm oil mills with higher production capacity were efficient in producing CPO than lower production capacity palm oil mills. Thus, the production cost of CPO was lower compared to that of small scale palm oil mills.
\end{abstract}

Key words: Crude palm oil (CPO), Palm oil mills, Production cost, Fresh Fruits Bunches (FFB), Free Fatty Acids (FFA), Part-Per-Million (PPM), export revenue, palm oil industry, Statistical analysis, million tons, Empty Fruit Bunch (EFB)

\section{INTRODUCTION}

The oil palm industry, which heavily depends on the world market, is an export oriented industry (Vijaya et al., 2009). The consumption of world palm oil increased over the years because the growing demand affected by the growing of food and oleo-chemical industries. The largest producers of palm oil products are mostly from Asian countries and Indonesia and Malaysia dominated the world palm oil market. Compared to other vegetable oils such as soybean oil and sunflower oil, price of palm oil products are cheaper (Rifin, 2010). The oil palm industry in Malaysia is very competitive and important. It contributes towards the economy of the country at a total of 22.40 million tons of oil palm products including palm oil, palm kernel oil, palm kernel cake, oleo-chemicals and finished products, equivalent to RM 49.59 billion of export revenue in year 2009 alone (Wahid, 2010). Higher profit margin is always the principle choices among traders. Hence, the lowest cost of production is the main objective to achieve by manufacturers. Malaysians government has signed free trade agreement (FTA) with potential buyers to ensure the cost always stayed low. Since Malaysia is the second largest palm oil producers in the world, accounting to 17.57 million tons from total of 45.06 million tons in 2009, one of the FTA was signed between Malaysia and Pakistan, called MalaysiaPakistan Closer Economic Partnership (MPCEPA) and the content included reducing import duty of palm oil products (Ministry of International Trade and Industry, 2007). According to Malaysian Palm Oil Board (MPOB), there were 416 mills operating in Malaysia in year 2009, 249 mills from Peninsular Malaysia and 167 from Sabah and Sarawak. There were 120 mills with total capacity 29,893,200 tones FFB per year located in Sabah alone. Total of 17,564,937 Metric Tons (MT) crude palm oil produced in year 2009 and $31.03 \%$ of total CPO was produced in Sabah (Malaysian Palm Oil

Corresponding Author: Elaine Lau Ying Man and Adam Baharum, Department of Operation Research, School of Mathematical Science, University Sains Malaysia, 11800 Pulau Pinang 
Board, 2009). Such a high percentage was mainly attributed to the largest oil palm planted state amounting for 1.36 million hectares or $29 \%$ of the total planted area in the country (Wahid, 2010).

Palm oil mills can be scaled by its FFB processing capacity; process 20 tons FFB per hour, 45 tons FFB per hour, 60 tons FFB per hour and 80 tons FFB per hour. All palm oil mills receive government assistance pertaining to leadership and impetus for development, scientific and technological support, transfer of knowledge and innovation and so on from Malaysian Palm Oil Board (MPOB), Malaysia Palm Oil Council (MPOC), Roundtable on Sustainable Palm Oil (RSPO), Palm Oil Research Institute of Malaysia (PORIM) (Ismail et al., 2003). There were some expos held in Sabah to bring together an international congregation of palm oil companies and supporting industries to showcase the latest development in the palm oil industry.

Minimum requirement to apply a mill license was first to own at least 10,000 acres of land planted with oil palms. Palm oil mills were built on new developing land or land planted with more than 20 years old oil palms rather than the planted land with no more than 20 years old oil palms or high profit return land to minimize the cost. Small scale palm oil mills targeted production cost for CPO lies between RM $45 \mathrm{~m} \mathrm{t}^{-1}$ to RM $50 \mathrm{~m} \mathrm{t}^{-1}$ while large scale palm oil mills less than $\mathrm{RM} 45 \mathrm{~m} \mathrm{t}^{-1}$. Production cost was inversely proportional to Oil Extraction Rate (OER). There were a lot of factors affecting OER such as amount of FFB being processed, ripeness, quality and moisture content of FFB, year of oil palms, type of soil, planting materials, machinery, manpower, technology and so on (Wahid and Simeh, 2009).

Figure 1 showed the flow chart of milling process. FFB from plantations are weighed and received at ramp. MPOB regulated a guideline for grading system according to ripeness. The FFB would be graded into ripe, un-ripe, over ripe, under ripe, empty, un-fresh, broken. There were two ways to evaluate the FFB; by visual expectation for small scale and old mills and rotated FFB by hopper in large scale mills.

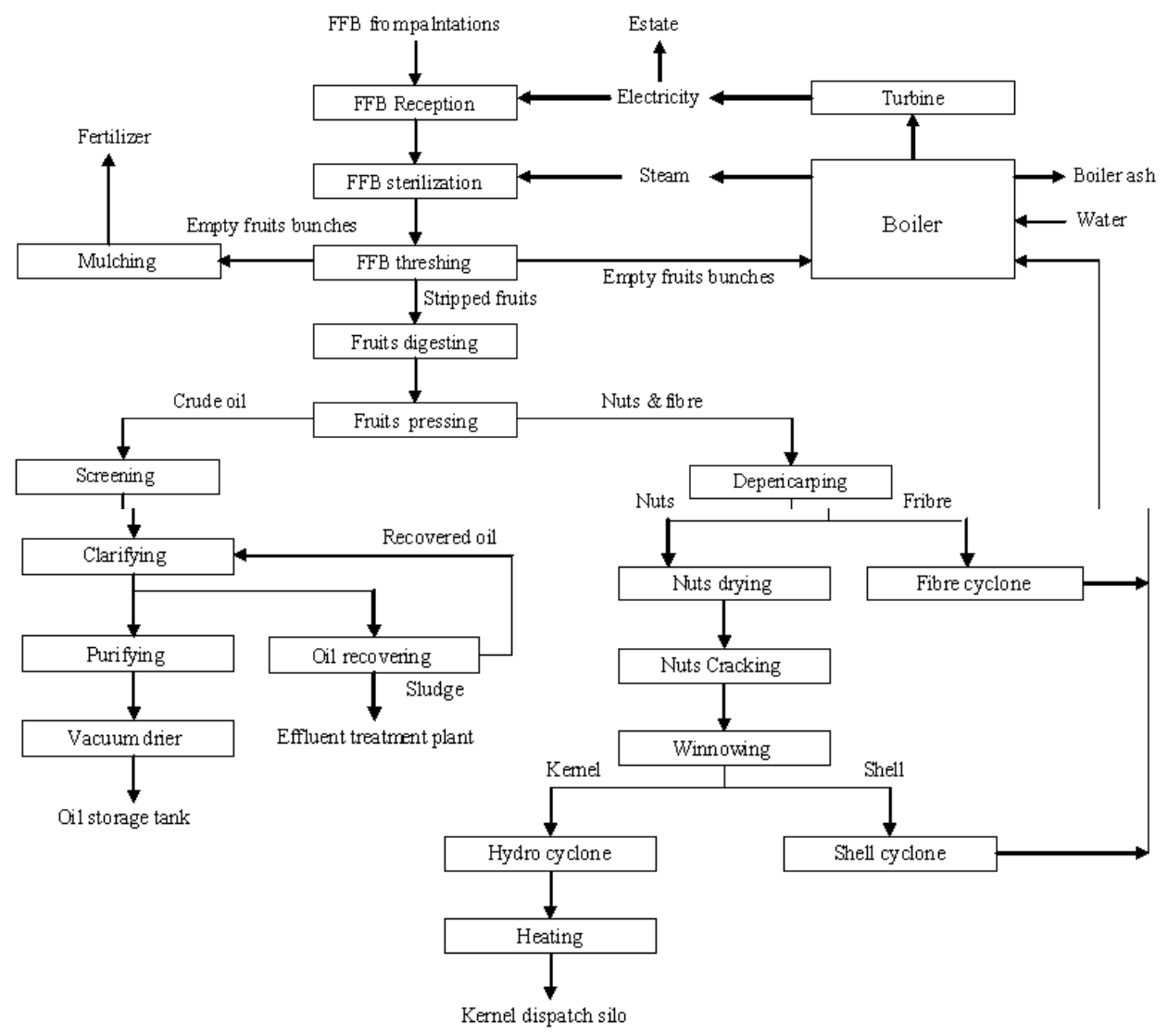

Fig.1: Flow chart for palm oil milling 
After evaluating, conveyor sends FFB in cages to sterilization station and steam at 45-50 pound-force per square inch gauge (psig) for 90 minutes. This process is to soften the mesorcarp, dehydrate the fruits and nuts. The steam also stops the enzymatic process which increasing the content of Free Fatty Acids (FFA) in oil. FFA is unwanted in palm oil so the industry tries to limit the content of FFA to less than 4\% (Subramaniam et al., 2010). The sterilized fruits are then sent to thresher to detach and separate the loose fruits from fruit bunch, called Empty Fruit Bunch (EFB). The EFB is used at boiler as fuel and also composited as fertilizer. Next, the fruitlets are sent to digester for further soften and rupturing oil bearing cell so that to release the oil. This step is also to homogenize fruitlets and condition the press cake and nuts. The fruitlets are finally sent to screw press to extract maximum oil and condition the press cake for kernel recovery. Mixture of oil, water and fruit solids at this point underflows to vibrating screen to remove most of the solid wastes. After screening, mixture of oil flow into clarifier tank to recover oil from diluted crude oil by static settling. At this point, two layers are formed; oil and sludge. Oil from upper layer flows into purifier to purify until the dirt less than $0.018 \%$ and is then transferred to vacuum drier to remove moisture content less than $0.2 \%$. The $\mathrm{CPO}$ is finally stored at oil storage tank with minimum or no deterioration of quality and waited to be sent off for exporting or refining at refineries. Sludge at bottom layer underflows to centrifuge for oil recovering. The recovered oil flows back to clarifier and repeat the processes while sludge is flew into effluent treatment plant. Nuts and fiber from press station undergo depericarping to separate nuts, fiber and foreign materials. Polished nuts are then dried and cracked to produce kernel and shell. Winnowing system separates the mixture and the kernel is sent to hydro cyclone. At this point, kernel is heated and stored in kernel dispatch silo to be sent off to kernel crushing plant and processed into crude palm kernel oil (CPKO). Finally, the fiber and shell from cyclones are used in boiler to produce steam and generate electricity. Higher production capacity POM produces more fiber, shells and EFB to be used as fuel in boiler. The electricity is self generated so that can save a lot of cost for fuel. The solid wastes from POM are EFB, fiber, shells and boiler ash while liquid waste is Palm Oil Mill Effluent (POME). These wastes were considered as priceless by products which contributed to generate electricity to operate POM and supply to estates as well. Both load required to generate electricity using biomass sources and to treat the amount of mesocarp fiber and kernel shell which have been removed from the environment because these by products were either recycled for self producing energy or used in plantations as fertilizers (Vijaya et al., 2008). The Biochemical Oxygen Demand (BOD) of POME waste needed to be reduced to 5000 Part-Per-Million (PPM) for land application and below 50 PPM for discharging to waterways by biological treatment (Vijaya et al., 2010). The gaseous emission from the effluent treatment plant includes methane, carbon dioxide and traces of hydrogen sulfide. According to a press in Sabah, there were 18 of POM treated the liquid waste and achieved the BOD at level of 20 milligram per litre before discharging into water courses and land (Admin, 2010). The number of POM complied with the requirement is expected to be increased gradually after adopting new environment protection technologies from Environment Department.

There were predictable and unpredictable variables caused production cost varied from time-to-time. Therefore, it is essential to identify the major cost influencing factors in the production of CPO.

\section{MATERIALS AND METHODS}

Sabah is the largest concentration of oil palm plantations and palm oil mills in Malaysia. Thus, this study based in Sabah. The study system started with collection of Fresh Fruits Bunches (FFB) at reception to the production of CPO stored in storage tank. Two palm oil mills of different production capacity, mill A of 20 tons FFB per hour and mill B of 60 tons FFB per hour, were selected to collect data from account departments. Mill A located in an island where mill B located on main land of Sabah. Data collection was carried out by on-site visits, interviews with mill managers and followed up by communications and discussions through e-mail. Statistical analysis was done to identify the major cost influencing factors of production cost for CPO.

\section{RESULTS}

Production cost for CPO was grouped according to mill operation cost, overheads cost, depreciation and other cost. Table 1-4 illustrated mill operation cost, mill overheads cost, mill depreciation cost and other cost in 2009 for mill A and mill B respectively. Mill operation cost included water and power, effluent treatment, upkeep of machinery, building and compound, laboratory, storage and dispatch while overhead cost were executives and staffs' salary, office and administrative expenses and labor recruitment. Other cost was CPO taxes. Total FFB processed in mill A was 97,016.47 mt while mill B was 336,659.04 $\mathrm{mt}$ in year 2009. Mill A was under supplied due to its location in an island. 
Am. J. Applied Sci., 8 (5): 441-446, 2011

Table 1: Operation cost in 2009

\begin{tabular}{|c|c|c|c|c|}
\hline \multirow[b]{2}{*}{ Particulars } & \multicolumn{2}{|l|}{ Mill A } & \multicolumn{2}{|l|}{ Mill B } \\
\hline & RM & $\mathrm{RM} / \mathrm{mt}$ & $\mathrm{RM}$ & $\mathrm{RM} / \mathrm{mt}$ \\
\hline Water \& Power & $473,724.14$ & 4.88 & $13,089.83$ & 0.04 \\
\hline Effluent treatment & 21,142.77 & 0.22 & 96,568.77 & 0.29 \\
\hline Upkeep machinery, building and compounds & $1,062,837.48$ & 10.96 & $4,087,372.73$ & 12.14 \\
\hline Laboratory & $67,384.76$ & 0.69 & $78,638.74$ & 0.23 \\
\hline Storage & $108,977.80$ & 1.12 & $179,463.25$ & 0.53 \\
\hline Dispatch & $692,218.51$ & 7.14 & $2,981,087.74$ & 8.85 \\
\hline Total & $2,426,285.46$ & 25.01 & $7,436,221.06$ & 22.09 \\
\hline
\end{tabular}

Table 2: Overheads cost in 2009

\begin{tabular}{|c|c|c|c|c|}
\hline \multirow[b]{2}{*}{ Particulars } & \multicolumn{2}{|l|}{ Mill A } & \multicolumn{2}{|l|}{ Mill B } \\
\hline & RM & $\mathrm{RM} / \mathrm{mt}$ & $\mathrm{RM}$ & $\mathrm{RM} / \mathrm{mt}$ \\
\hline $\begin{array}{l}\text { Supervision-executive and staff } \\
\text {. }\end{array}$ & $488,876.65$ & 5.04 & $774,515.85$ & 2.30 \\
\hline Office and administrative expenses & $298,278.47$ & 3.07 & $255,727.89$ & 0.76 \\
\hline Labor recruitment & $521,637.86$ & 5.38 & $263,900.84$ & 0.78 \\
\hline Total & $1,308,792.98$ & 13.49 & $1,294,144.58$ & 3.84 \\
\hline
\end{tabular}

Table 3: Depreciation cost in 2009

\begin{tabular}{lllll}
\hline & \multicolumn{2}{l}{ Mill A } & & \multicolumn{2}{l}{ Mill B } & \\
Particulars & RM & RM/mt & RM & RM/mt \\
\hline CPO taxes & $220,110.00$ & 2.27 & $174,327.61$ & 0.52 \\
\hline
\end{tabular}

Table 4: Other cost in 2009

\begin{tabular}{lllll}
\hline & Mill A & & \multicolumn{2}{l}{ Mill B } \\
Particulars & RM & RM/mt & RM & \\
\hline Depreciation & $689,191.62$ & 7.10 & $3,297,717.36$ & 9.80 \\
\hline
\end{tabular}

\section{DISCUSSION}

Operation cost: The cost of operation for mill A was RM 2,426,285.46 while mill $B$ was RM 7,436,221.06, equivalent to RM 25.01/mt and RM $22.09 \mathrm{~m} \mathrm{t}^{-1}$ respectively in year 2009. The major cost item was upkeep machinery, building and compounds which constituting about $44 \%$ for mill A and $55 \%$ for mill B of the total operation cost. Most of the cost allocated to purchase and maintain machines, building and compounds because these were the most important assets to operate the mills. Cost of water and power for mill A was RM 473,724.14 or RM $4.88 \mathrm{~m} \mathrm{t}^{-1}$, which was higher than mill $\mathrm{B}, \mathrm{RM}$ $13,089.83$ or RM $0.04 \mathrm{~m} \mathrm{t}^{-1}$. Mill A used more diesel to operate the generator before the activation of turbine. When there is enough EFB, fiber and shells to be burnt out in the boiler, the generation of power shifts to turbine instead of using diesel generator. Since mill A only processed 20 ton FFB per hour, it took longer time to activate the turbine compare to mill $\mathrm{B}$, which can processed 60 ton FFB per hour. Cost of dispatch for mill A was RM 7.14/mt which was lower than mill B, RM 8.85 $\mathrm{m} \mathrm{t}^{-1}$. Distances of both mills from town were $147 \mathrm{~km}$ and $250 \mathrm{~km}$ respectively. Mill A located near to river and the CPO is dispatched to refinery mills through river while mill B located apart from river. So, mill B transferred CPO by hiring tankers and trailers to jetty before dispatching $\mathrm{CPO}$ to refineries through river. Effluent treatment plant is a system used to treat the sludge from palm oil mill before discharging to the river in order to fulfill the Biochemical Oxygen Demand (BOD) as required by MPOB, which is below 50 Part-Per-Million (PPM) (Subramaniam et al., 2010). Treatment cost for both mills were RM $0.22 \mathrm{~m} \mathrm{t}^{-1}$ and RM $0.29 \mathrm{~m} \mathrm{t}^{-1}$ respectively. Cost for mill A was lower due to its production capacity and thus the waste was lower. Costs for laboratory and storage of mill A doubled the costs of mill B. Mill A transferred CPO to refineries twice a month so the cost allocated to control the FFA was higher than mill $\mathrm{B}$.

Overheads cost: Overheads cost can be a significant input and therefore may account for a large proportion of the production cost for CPO. Overheads cost for mill A amounted to RM 13.49/mt which was RM 9.65/mt more than mill B. Based on organization charts for both mills, the number of administrative staffs were almost same so cost for both mills were almost same. However, total FFB processed in year 2009 for mill A was 97,016.47 mt while mill B was 336,659.04 mt, which was a big difference with 239,642.57 mt. Besides, labor recruitment cost for mill A more than mill B due to the use of machineries. Mill B allocated more cost in machineries and thus only recruited few labors to supervise the running of machines during mill processing. Therefore, the overheads cost per metric ton for smaller production capacity mill was higher than larger production capacity mill. 
Am. J. Applied Sci., 8 (5): 441-446, 2011

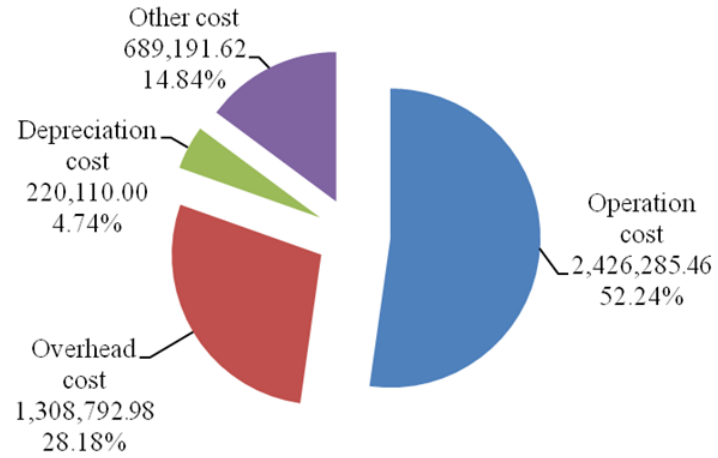

Fig. 2: Summary of production cost for CPO in mill A

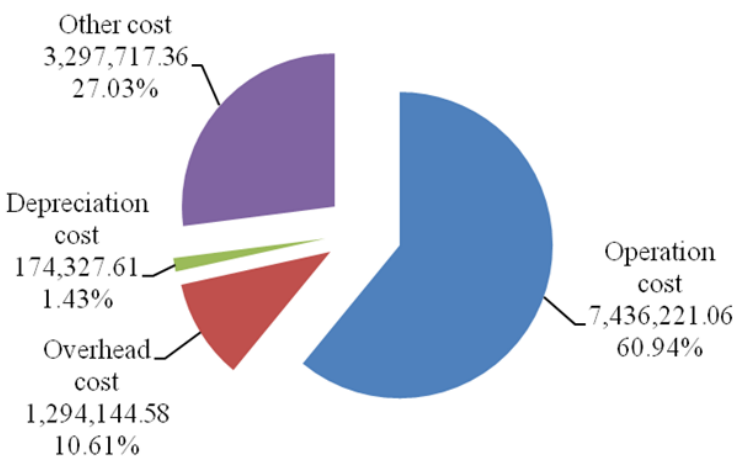

Fig. 3: Summary of production cost for CPO in mill B

Table 5: Comparison of OER and production cost for both mills in 2009

\begin{tabular}{lll}
\hline & Mill A & Mill B \\
\hline Production capacity (ton/hr) & 20 & 60 \\
FFB processed (mt) & $97,016.47$ & $336,659.04$ \\
CPO produced (mt) & $20,001.23$ & $73,275.67$ \\
OER \% & $20.62 \% 0000$ & $21.77 \% 000$ \\
Production cost (RM/mt) & 47.87 & 36.25 \\
\hline
\end{tabular}

Other costs: This category included CPO taxes such as sale taxes to MPOB, jetty fees on river, quit rent and so on. Mill A's CPO taxes was RM 1.75/mt more than mill B's because mill A paid jetty fees for river dispatched.

Depreciation cost: Finally, depreciation cost for mill A was much lower than mill B; RM $7.10 \mathrm{~m} \mathrm{t}^{-1}$ for mill A and RM $9.80 \mathrm{~m} \mathrm{t}^{-1}$ for mill B. Number of machines and building's compound were more often related to depreciation cost. Mill B has higher numbers of machinery than mill $\mathrm{A}$ and the building's compound of mill B was larger than mill A due to the production capacity of mill B. Building's depreciation cost often related to defection of building over time such as steel corrosion.

Cost summary: Figure 2-3 reveal summary of production cost for CPO in both mills. Total cost of
CPO production for both mills was RM 4,644,380.06 and RM 12,202,410.61. In terms of tonnage, it implied that for every ton of FFB, the production cost was RM 47.87 and RM 36.25 respectively. The highest cost component was operation cost, which amounted to RM $25.01 \mathrm{~m} \mathrm{t}^{-1}$ and RM $22.09 \mathrm{~m} \mathrm{t}^{-1}$ for both mills. This cost component represented $52.24 \%$ and $60.94 \%$ of the production cost respectively. For mill A, the second most important cost item was overheads cost amounted to $28.18 \%$, followed by depreciation with $14.84 \%$ and other costs with $4.74 \%$. Mill B's second large portions of costing item was depreciation cost amounted to $27.03 \%$, followed by overheads cost with $10.61 \%$ and the last other costs with $1.43 \%$. The CPO production cost for small scale palm oil mills preferably lied between RM 45-50 per metric tons while large scale palm oil mills lied below RM 45 per metric tons.

Oil extraction rate: Table 5 showed OER of mill A and mill B. OER was obtained by dividing amount of CPO produced with amount of FFB processed. OER for mill A was lower than mill B due to production capacity. Higher production capacity possessed higher OER and lower production cost.

\section{CONCLUSION}

The study reveals that in year 2009, POM with higher production capacity is efficient in producing CPO than lower production capacity POM. The major cost influencing factor for both mills was determined. Mill A saved dispatch cost to refinery mills due to its strategic location near river. Meanwhile, mill B could not avoid from high depreciation cost of machineries. So, they saved cost from labor recruitment. It is also deduced from the study that the OER affected the production cost of CPO where OER directly proportionate to production capacity and inversely proportionate to $\mathrm{CPO}$ production cost. Both oil palm plantation companies and palm oil mills can control the predictable variables such as FFB's ripeness, FFB's quality, year of oil palms, planting materials, machinery, manpower and so on. A better alternative to save the CPO production cost is to use wastes from POM such as EFB, fiber and shells as fuel in boiler. It is strongly recommended to capture biogas and use it to generate renewable energy in POM. Cost management and operational efficiency also played important roles in production cost of CPO. In managing cost, factors affecting cost must be addressed so that suitable solutions could be figured out immediately. Research and development of planting materials, machineries, technologies are carried out by supporting institutions to improve the quality of FFB and thus to increase 
OER. Therefore, all parties have to be cooperated to keep the cost at the most competitive level and to ensure a better future for palm oil industry.

\section{ACKNOWLEDGEMENT}

The researchers would like to thank the palm oil millers for allowing conducting the study in mills and University Sains Malaysia providing fellowship and grant 1001/PMATHS/823005 which enable the research to carry out smoothly.

\section{REFERENCES}

Admin, 2010. Effluent discharge: 18 Sabah oil mills comply. Palm Oil Prices.net: http://www.palmoilprices.net/news/effluentdischarge-18-sabah-oil-mills-comply/

Ismail, A., M.A. Simeh and M.M. Noor, 2003. The production cost of oil palm fresh fruit bunches: the case of independent smallholders in Johor. Oil Palm Industry Econ. J., 3: 1-7.

Malaysian Palm Oil Board, 2009. Palm Oil Infromation Online Service. Malaysian Palm Oil Board: http://palmoilis.mpob.gov.my/

Ministry of International Trade and Industry, 2007. Ministry of International Trade and Industry. Malaysia's Trade and Industry: http://www.miti.gov.my/cms/content.jsp?id=com.t ms.cms.article.Article_ecef6f61-7f00001016251625-d1ff24f1
Rifin, A., 2010. Export competitiveness of Indonesia's palm oil product. Trends Agric. Econ., 3: 1-18. DOI: 10.3923/tae.2010.1.18

Subramaniam, V., C.Y. May, H. Muhammad, Z. Hashim and Y.A. Tan et al., 2010. Life cycle assesment of the production of crude palm oil (Part 3). J. Oil Palm Res., 22: 895-903.

Vijaya, S., A. Ma and Y. Choo, 2010. Capturing biogas: A means to reduce green house gas emissions for the production of crude palm oil. Am. J. Geosci., 1: 1-6. DOI: 10.3844/ajgsp.2010.1.6

Vijaya, S., A. Ma, Y. Choo and N.N. Meriam, 2008. Environment performance of the milling process of malaysian palm oil using the life cycle assesment approach. Am. J. Environ. Sci., 4: 310-315. DOI: 10.3844/ajessp.2008.310.315

Vijaya, S., A. Ma and Y. Choo, 2009. A gate to gate assesment of environmental performance for production of crude palm kernel oil using life cycle assesment approach. Am. J. Environ. Sci., 5: 267272. DOI: 10.3844/ajessp.2009.267.272

Wahid, D.D., 2010. Overview of the Malaysian Oil Palm Industry 2009. Malaysian Palm Oil Board, Bangi. http://econ.mpob.gov.my/economy/Overview_200 9.pdf

Wahid, M.B. and M.A. Simeh, 2009. Issues relater to production cost of palm oil in Malaysia. Oil palm Industry Econ. J., 9: 1-12. http://palmoilis.mpob.gov.my/publications/opiejv9 n2-basri.pdf 